Available online on 15.07.2017 at http://jddtonline.info
Journal Of Drug Delivery and Therapeutics
Open Access to Pharmaceutical and Medical Research
$\begin{gathered}\text { @ 2011-17, publisher and licensee JDDT, This is an Open Access article which permits unrestricted } \\ \text { noncommercial use, provided the original work is properly cited }\end{gathered}$

Open $\odot$ Access

Research Article

\title{
ANTIOXIDANT ACTIVITY OF ETHANOLIC EXTRACT OF OCIMUM KILIMANDSCHARICUM USING HYDROXYL RADICAL SCAVENGING METHOD
}

\author{
Joshi Tanuj ${ }^{* 1}$, Juyal Vijay ${ }^{2}$ \\ ${ }^{1}$ Teaching Personnel, Department of Pharmaceutical Sciences, Bhimtal (Kumaun University), Pin-263136, Uttarakhand, India \\ ${ }^{2}$ Professor, Department of Pharmaceutical Sciences, Bhimtal (Kumaun University), Pin-263136, Uttarakhand, India
}

\begin{abstract}
In our modern society, we are constantly being challenged by numerous diseases. Majority of these diseases are as a result of the stressful and unhealthy lifestyle that has been adopted by modern man. Due to the polluted environment, unhealthy lifestyles and fast food culture there is overproduction of reactive oxygen and nitrogen species in human body. These reactive oxygen and nitrogen species have become the most important culprits for the development of neurodegenerative diseases, cardiovascular diseases, autoimmune diseases, aging and many other diseases. Newer findings in the etiology of various diseases have implicated free radicals and oxidative species in the development of various diseases. So, to find the newer treatments of various diseases we should deeply research the area of antioxidants. Nature has provided us with various medicinal plants which contain phytochemicals that have potent antioxidant potentials. Himalayan herbs have been known since time immemorial to cure even uncurable diseases. The current study focuses on the antioxidant potential of ethanolic extract of aerial parts of Ocimum kilimandscharicum at very low concentrations using hydroxyl radical scavenging activity. This study aims to unravel the potentials of truly potent herbs in the field of antioxidants, which in future can provide cure to several diseases.
\end{abstract}

Keywords: antioxidants, free radicals, Ocimum kilimandscharicum.

Article Info: Received 12 June, 2017; Review Completed 10 July, 2017; Accepted 11 July, 2017; Available online 15 July, 2017

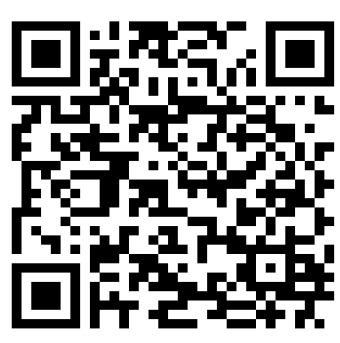

Cite this article as:

Joshi T, Juyal V, Antioxidant activity of ethanolic extract of Ocimum kilimandscharicum using hydroxyl radical scavenging method, Journal of Drug Delivery and Therapeutics. 2017; 7(4):66-68

DOI: http://dx.doi.org/10.22270/jddt.v7i4.1470

${ }^{*}$ Address for Correspondence

Tanuj Joshi, Teaching Personnel, Department of Pharmaceutical Sciences, Bhimtal (Kumaun University), Pin-263136, Uttarakhand, India. Email: tanujjoshi34@yahoo.co.in

\section{INTRODUCTION}

Oxidative stress has now become a major concern for human health. Numerous diseases are a consequence of oxidative stress. In oxidative stress there is overproduction of reactive oxygen and nitrogen species in the body. In humans cells use oxygen to generate energy and free radicals are produced as a consequence of ATP (adenosine triphosphate) production by the mitochondria. Production of reactive species is a normal phenomenon but when there is overproduction of reactive oxygen and nitrogen species in the body, there is significant damage to the body and it leads to various disease conditions. Numerous diseases such as cancer, arthritis, aging, autoimmune disorders, cardiovascular and neurodegenerative diseases are a result of oxidative stress. Free radicals cause damage to cells and tissues by reacting with lipids, DNA and proteins ${ }^{1}$. Human body has natural antioxidants like glutathione which can scavange free radicals but when there is overproduction of oxidants the body's antioxidant system becomes ineffective and cannot scavenge free radicals. Synthetic antioxidants, such as butylated hydroxyanisole (BHA), butylated hydroxytoluene (BHT), have been widely used 
in the food industry but they can cause toxicity to liver and carcinogenicity ${ }^{2}$. Thus, there is an urgent need for antioxidants belonging to natural origin. Phytochemicals with good antioxidant potential can combat oxidative stress in human body to a great extent.

Herbs can be a potential answer to oxidative stress. In the present study Ocimum kilimandscharicum Guerke. is taken as the medicinal plant, whose ethanolic extract of aerial parts has been evaluated for antioxidant activity using hydroxyl radical scavenging method. Ocimum kilimandscharicum is commonly called kapur tulsi or camphor basil. It an undershrub. Ocimum kilimandscharim is a native plant of Kenya (East Africa), and was introduced and cultivated in India. The leaves are ovate or oblong, acute, narrow at base, deeply serrated, pubescent on both surfaces. Flowers are 4-6 flowers in whorl. Ocimum kilimandscharicum can be easily propagated through seeds, it has been grown in Uttar Pradesh, West Bengal, Maharashtra, Mysore, Madras, Kerala and Jammu. It has also thrived well in lower hills of Darjeeling. In Uttarakhand also it is grown in some regions. The plant can withstand high temperatures provided it gets sufficient moisture, it cannot withstand low temperatures below $30^{\circ} \mathrm{F}$. It thrives well in areas of annual rainfall of $125 \mathrm{~cm}^{3}$. Essential oil of aerial parts of Ocimum kilimandscharicum contains the following ingredients: $\alpha$-pinene $(1.23 \%)$, camphene (7.32\%), $\beta$-myrcene $(1.58 \%), \alpha$-phellandrene $(0.26 \%)$, $\alpha$-terpinene ( $0.33 \%), p$-cymene( $0.62 \%)$, DL-limonene (13.56\%), 1,8-cineole $(0.85 \%), \beta$-ocimene $(2.00 \%)$, $\gamma$-terpinene $(0.88 \%)$, cis-sabinene hydrate $(0.47 \%)$, $\alpha$-terpinolene $(1.33 \%)$, trans-sabinene hydrate $(0.49 \%)$, linalool (1.70\%), camphor $(56.07 \%)$, terpinen-4-ol (3.50\%), myrtenol (1.24\%), trans-caryophyllene $(0.33 \%)$, germacrene D $(0.43 \%)$ as there constituents ${ }^{4}$. Leaves of Ocimum kilimandscharicum contain flavonoids, tannins, saponins, sterols, carbohydrates, proteins and triterpenoids ${ }^{5}$. Essential oil obtained from the leaves of Ocimum kilimandscharicum is used for making camphor and it is commercially expoited for this purpose $^{6}$.

\section{MATERIAL AND METHODS}

\section{Plant collection and authentication}

Aerial parts of Ocimum kilimandscharicum were collected from herbal garden of Defence Institute of Bioenergy Research, Panda Farm, Pithoragarh and authenticated by ICAR- National Bureau of Plant Genetic Resources, Regional station, Niglat, Bhowali, Uttarakhand.

\section{Preparation of the extract}

Aerial parts of Ocimum kilimandscharicum were dried, powdered and extracted with absolute ethanol (99.9\%) using soxhlet's assembly. The extract was then dried using rotator vaccum flash evaporator ${ }^{7}$.

\section{Hydroxyl Radical Scavenging Activity}

The dried extract obtained was sent to Deshpande laboratories private limited, Bhopal, Madhya Pradesh, India for analyzing hydroxyl radical scavenging activity and the following method was used by Deshpande labs: Hydroxyl radical scavenging activity was measured by the ability of the different fractions of extract to scavenge the hydroxyl radicals generated by the $\mathrm{Fe}^{3+}$ ascorbate-EDTA- $\mathrm{H}_{2} \mathrm{O}_{2}$ system (Fenton reaction). The reaction mixture in a final volume of $1.0 \mathrm{ml}$ contained $100 \mu \mathrm{l}$ of 2-deoxy-D-ribose $\left(28 \mathrm{mM}\right.$ in $20 \mathrm{mM} \mathrm{KH_{2 }} \mathrm{PO}_{4}$ buffer, $\mathrm{pH} 7.4), 500 \mu \mathrm{l}$ of the fractions at various concentrations $(0.0001-50 \mu \mathrm{g} / \mathrm{ml})$ in buffer, $200 \mu \mathrm{l}$ of $1.04 \mathrm{mM}$ EDTA and $200 \mu \mathrm{M} \mathrm{FeCl}_{3}(1: 1, \mathrm{v} / \mathrm{v}), 100 \mu \mathrm{l}$ of $1.0 \mathrm{mM}$ hydrogen peroxide $\left(\mathrm{H}_{2} \mathrm{O}_{2}\right)$ and $100 \mu \mathrm{l}$ of 1.0 $\mathrm{mM}$ ascorbic acid. Test samples were kept at $37^{\circ} \mathrm{C}$ for 1 h. The free radical damage imposed on the substrate, deoxyribose was measured using the thiobarbituric acid test. One $\mathrm{ml}$ of $1 \%$ thiobarbituric acid (TBA) and $1.0 \mathrm{ml}$ $2.8 \%$ trichloroacetic acid (TCA) were added to the test tubes and was incubated at $100^{\circ} \mathrm{C}$ for $20 \mathrm{~min}$. After cooling, the absorbance was measured at $532 \mathrm{~nm}$ against a blank containing deoxyribose and buffer. Ascorbic acid was used as the standard. The plate were read on BMG Fluostar (GERMANY) and the \% inhibition data was analyzed on MARS software BMG (Germany).

\section{RESULTS}

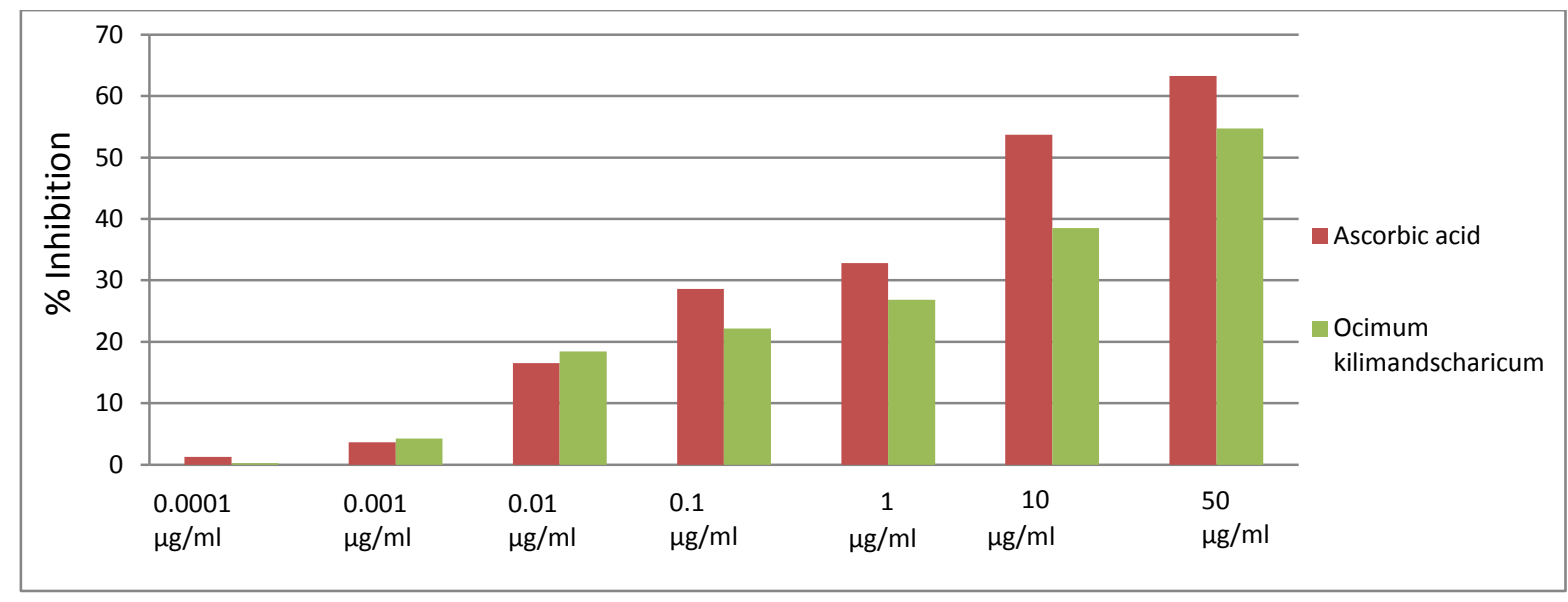

Figure 1: Percentage inhibition produced by ascorbic acid and Ocimum kilimandscharicum at seven different concentrations using hydroxyl radical scavenging method 
Table 1: Percentage inhibition produced by Ocimum kilimandscharicum at seven different concentrations using hydroxyl radical scavenging method

\begin{tabular}{|l|l|}
\hline Concentration $(\mu \mathrm{g} / \mathrm{ml})$ & \% Inhibition (Ocimum kilimandscharicum) \\
\hline 0.0001 & 0.25 \\
\hline 0.001 & 4.25 \\
\hline 0.01 & 18.45 \\
\hline 0.1 & 22.15 \\
\hline 1 & 26.84 \\
\hline 10 & 38.48 \\
\hline 50 & 54.76 \\
\hline
\end{tabular}

\section{DISCUSSION}

Hydroxyl radicals are important active oxygen species that cause lipid peroxidation and enormous biological damage. They are the most reactive oxygen centered species and causes severe damage to adjacent biomolecules $^{8}$. In the present study ethanolic extract of aerial part of Ocimum kilimandscharicum showed $0.25 \%$ inhibition of hydroxyl radical at $0.0001 \mu \mathrm{g} / \mathrm{ml}$ concentration (Table. 1) and this percentage inhibition increased on increasing the concentration, with maximum percentage inhibition of 54.76 at $50 \mu \mathrm{g} / \mathrm{ml}$ (Table 1.), so a concentration dependent effect on hydroxyl radical scavenging ability was observed, thus as the concentration of Ocimum kilimandscharicum was increased, the percentage inhibition also increased. Ascorbic acid was used as the standard in the present study. At most concentrations ascorbic acid showed better activity than Ocimum kilimandscharicum except at $0.001 \mu \mathrm{g} / \mathrm{ml}$ and $0.01 \mu \mathrm{g} / \mathrm{ml}$ (Figure 1.), where Ocimum kilimandscharicum showed better activity than ascorbic acid. Overall Ocimum kilimandscharicum produced effects comparable to ascorbic acid and it can thus be said that Ocimum kilimandscharicum showed hydroxyl radical scavenging activity at very low concentrations. There are many important phytochemicals present in Ocimum kilimandscharicum and these might be responsible for the antioxidant activity of Ocimum kilimandscharicum.

\section{REFERENCES}

1. Huy LAP, He H, Huy CP, Free Radicals, Antioxidants in Disease and Health, International Journal of Biomedical Science, 2008; 4(2):89-96.

2. Babu D, Gurumurthy P, Borra SK, Cherian KM, Antioxidant and free radical scavenging activity of triphala determined by using different in vitro models, Journal of Medicinal Plant Research, 2013; 7(39):2898-2905.

3. The Wealth of India: A dictionary of Indian Raw Materials and Industrial Products. Raw Materials Vol. VII: N-Pe. New Delhi: The Council of Scientific and Industrial Research; 2007.P. 85-87.

4. Kumar AA, Mohan M, Haider SZ, Sharma A, Essential oil composition and antimicrobial activity of three Ocimum

\section{CONCLUSION}

It has been discussed previously that reactive oxidative species and nitrogen species are a major source of diseases in humans. They have produced a drastic and damaging effect on human health. Our hectic lifestyle and adulterated food has disturbed the metabolic processes of our body. The disturbances in our metabolic processes have led to oxidative stress and this oxidative stress has affected our health. Synthetic antioxidants like butylated hydroxyl toluene cannot be used in humans on a regular basis because of their damaging effects. Thus, herbal drugs can be developed which will scavenge the free radicals and provide relief from oxidative stress. Himalayan herbs have always shown promising effect on various types of diseases. Ocimum kilimandscharicum is a native plant of Africa but is now been grown in India. Ocimum kilimandscharicum, which was collected from the fresh and clean environment of Pithoragarh, Uttarakhand has shown very good antioxidant activity in the present study. The antioxidant activity of the ethanolic extract of Ocimum kilimandscharicum was comparable to the standard antioxidant ascorbic acid. Thus in near future potent medicines can be developed from Ocimum kilimandscharicum which can fight oxidative stress.

species from Uttarakhand (India), International Journal of Pharmacy and Pharmaceutical Sciences, 2011; 3:223-225.

5. Paschapur MS, Patil MB, Kumar R, Patil SR, Evaluation of aqueous extract of leaves of Ocimum kilimandscharicum on wound healing activity in albino wistar rats, International Journal of Pharmtech Research, 2009; 1:544-550.

6. Sharma R. Medicinal Plants of India- An Encyclopedia. Delhi: Daya Publishing House; 2003. P. 175.

7. Kokate CK, Purohit AP, Gokhale SB. Pharmacognosy. 45th ed. Pune: Nirali Prakashan; 2010. P. 6.15-6.16.

8. Aurand LW, Boonnmen NH, Gidding GG, Superoxide and singlet oxygen in milk lipid peroxidation. Journal of Dairy Science, 1977; 60:363-369. 